\title{
Blood Group B
}

National Cancer Institute

\section{Source}

National Cancer Institute. Blood Group B. NCI Thesaurus. Code C76247.

A blood group indicating the presence on erythrocytes of only the $B$ form of the $\mathrm{H}$ Antigen. 